\title{
Bisphenol AF as an activator of human estrogen receptor $\beta 1$ (ERß1) in breast cancer cell lines
}

\author{
Hiroyuki Okazaki 1,*, Masayo Hirao-Suzuki ${ }^{2, *}$, Shuso Takeda², Yukimi Takemoto', \\ Ramu Mizunoe' ${ }^{1}$, Koichi Haraguchi ${ }^{3}$, Kazuhito Watanabe ${ }^{4}$, Masufumi Takiguchi \\ and Hironori Aramaki ${ }^{1}$
}

\author{
${ }^{1}$ Department of Molecular Biology, Daiichi University of Pharmacy, \\ 22-1 Tamagawa-cho, Minami-ku, Fukuoka 815-8511, Japan \\ ${ }^{2}$ Laboratory of Xenobiotic Metabolism and Environmental Toxicology, Faculty of Pharmaceutical Sciences, \\ Hiroshima International University (HIU), 5-1-1 Hiro-koshingai, Kure, Hiroshima 737-0112, Japan \\ ${ }^{3}$ Analytical Chemistry, Daiichi University of Pharmacy, 22-1 Tamagawa-cho, Minami-ku, Fukuoka 815-8511, Japan \\ ${ }^{4}$ Center for Supporting Pharmaceutical Education, Daiichi University of Pharmacy, \\ 22-1 Tamagawa-cho, Minami-ku, Fukuoka 815-8511, Japan
}

(Received December 8, 2017; Accepted February 23, 2018)

\begin{abstract}
Bisphenol AF (BPAF) is now recognized as one of the replacements for bisphenol A (BPA). Although considerable experimental evidence suggests that BPA is an endocrine-disrupting chemical, the toxicological profile of BPAF has been investigated in less detail than that of BPA, even at the in vitro level. BPAF has been established as an activator of estrogen receptor $\alpha(E R \alpha)$ in many cell lines; however, controversy surrounds its effects on the other isoform, ER $\beta$ (i.e., whether it functions as a stimulator). Five human ER $\beta$ isoforms have been cloned and characterized. Of these, we focused on the interactions between BPAF and the two isoforms, ER $\beta 1$ and ER $\beta 2$. We demonstrated that i) BPAF functioned as a stimulator of $E R \beta 1$ (and $E R \alpha$ ), which is transiently expressed in the two types of human breast cancer cells (MDA-MB-231 and SK-BR-3 cells) $\left(\mathrm{EC}_{50}\right.$ values for $\mathrm{ER} \beta$ : $6.87 \mathrm{nM}$ and $2.58 \mathrm{nM}$, respectively, and $\mathrm{EC}_{50}$ values for $\mathrm{ER} \alpha: 24.7 \mathrm{nM}$ and $181 \mathrm{nM}$, respectively), ii) the stimulation of ER $\beta 1$ by BPAF $(1-25 \mathrm{nM}$ ) was abrogated by PHTPP (an ER $\beta$ selective antagonist), and iii) the expression of ER $\beta 1$ and ER $\beta 2$ was not modulated by BPAF at nanomolar concentrations up to $25 \mathrm{nM}$. These results indicate that BPAF activates not only human ER $\alpha$, but also the ER $\beta 1$ isoform in breast cancer cells, and exhibits higher activation potency for ER $\beta 1$.
\end{abstract}

Key words: Bisphenol AF, BPAF, ER $\beta 1$, MDA-MB-231 cells, SK-BR-3 cells

\section{INTRODUCTION}

Estrogens including $17 \beta$-estradiol (E2) are essential for the development and maintenance of the reproductive organs. Estrogens generally utilize two estrogen receptors (ERs), ER $\alpha$ (ESR1) and ER $\beta$ (ESR2), to induce a number of physiological effects as ligands (Shanle and $\mathrm{Xu}, 2011$ ). Endocrine-disrupting chemicals (EDCs) are compounds that interfere with hormone biosynthesis, metabolism, or signaling. In interactions between EDCs and estrogen signaling, many EDCs are known to exhibit estrogenic/antiestrogenic activities, which are, at least in part, mediated by the two ERs (Shanle and Xu, 2011). EDCs have been shown to modulate normal estrogen signaling in two manners: 1) a direct/indirect interaction with ERs (as ligands) and 2) the up-/down-regulation of ERs. The physiological functions of ER $\beta$ have not yet been examined in as much detail as those of $E R \alpha$, including the effects of EDCs on the five ER $\beta$ isoforms: ER $\beta 1, E R \beta 2$ (also called ER $\beta c x$ ), ER $\beta 3$ (restricted to the testis), ER $\beta 4$, and ER $\beta 5$ (Moore et al., 1998; Leung et al., 2006; Sugiyama et al., 2010).

Bisphenol A (BPA), a monomer used in polycarbonate plastic and polystyrene resins, is regarded as an endocrine-disrupting chemical that perturbs estrogen signaling by acting as a ligand for ER $\alpha$ and ER $\beta$ (Rochester, 2013). Due to the toxic effects of high levels of BPA, it is being

Correspondence: Shuso Takeda (E-mail: s-takeda@ps.hirokoku-u.ac.jp)

Hironori Aramaki (E-mail: haramaki@daiichi-cps.ac.jp)

*These authors equally contributed to this work. 
replaced with analogs that are structurally similar, such as bisphenol B (BPB), bisphenol S (BPS), and bisphenol AF (BPAF). Among these bisphenols, the abnormal nature of BPAF (a fluorinated derivative of BPA: $-\mathrm{CF}_{3}$ ) (See Fig. 1A) has been reported; it has been shown to more strongly accumulate in hepatocytes than parent BPA even though the hallmark of lipophilicity (e.g., $P_{\text {ow }}$ ) of BPAF is not as high as that of BPA (HSDB, 2001; NTP, 2008; Waidyanatha et al., 2015). Furthermore, studies on BPA and BPAF demonstrated that the activity of the latter for "ER $\beta$ " depended on the cell type employed (Matsushima et al., 2010; Li et al., 2012). There is currently no experimental evidence to show whether BPAF affects the transcriptional activity of $E R \beta$ in the human breast cancer cell lines, MDA-MB-231 and SK-BR-3. Therefore, we herein evaluated the effects of BPAF on ER $\beta$ activity in these two breast cancer cell lines transfected with human ER $\beta$ cDNA.

\section{MATERIALS AND METHODS}

\section{Reagents}

BPA [2,2-bis(4-hydroxy phenyl)propane] (purity: $>99 \%$ ) was purchased from Wako Pure Chemical Industries (Osaka, Japan). BPAF [1,1,1,3,3,3-hexafluoro2,2-bis(4-hydroxy phenyl)propane] (purity: > 98\%), ВРВ [2,2-bis(4-hydroxyphenyl)butane] (purity: $>98 \%$ ), and BPS [bis(4-hydroxyphenyl)sulfone] (purity: > 98\%) were purchased from Tokyo Chemical Industry (Tokyo, Japan). PHTPP (purity: > 99\%) was purchased from Tocris Biosciences (Ellisville, MO, USA). All other reagents were of the highest grade commercially available.

\section{Cell cultures}

The conditions/methods of cell cultures were described previously (Takeda et al., 2012, 2013). Briefly, the human breast cancer cell lines, MDA-MB-231 and SK-BR-3 (obtained from the American Type Culture Collection, Rockville, MD, USA) were routinely grown in phenol red-containing minimum essential medium $\alpha(\mathrm{MEM} \alpha)$ (Invitrogen, Carlsbad, CA, USA), supplemented with 10 mM HEPES [4-(2-hydroxyethyl)-1-piperazineethanesulfonic acid], 5\% fetal bovine serum, penicillin $(100 \mathrm{U} / \mathrm{mL})$, and streptomycin $(100 \mu \mathrm{g} / \mathrm{mL})$ in a humidified incubator, within an atmosphere of $5 \% \mathrm{CO}_{2}$ at $37^{\circ} \mathrm{C}$. Prior to chemical treatments, culture medium was changed to phenol red-free MEM $\alpha$ (Invitrogen) supplemented with $10 \mathrm{mM}$ HEPES, 5\% dextran-coated charcoal-treated fetal bovine serum, penicillin $(100 \mathrm{U} / \mathrm{mL})$, and streptomycin $(100 \mu \mathrm{g} / \mathrm{mL})$. Cultures of approximately subconfluence in a $100-\mathrm{mm}$ Petri dish were used to seed

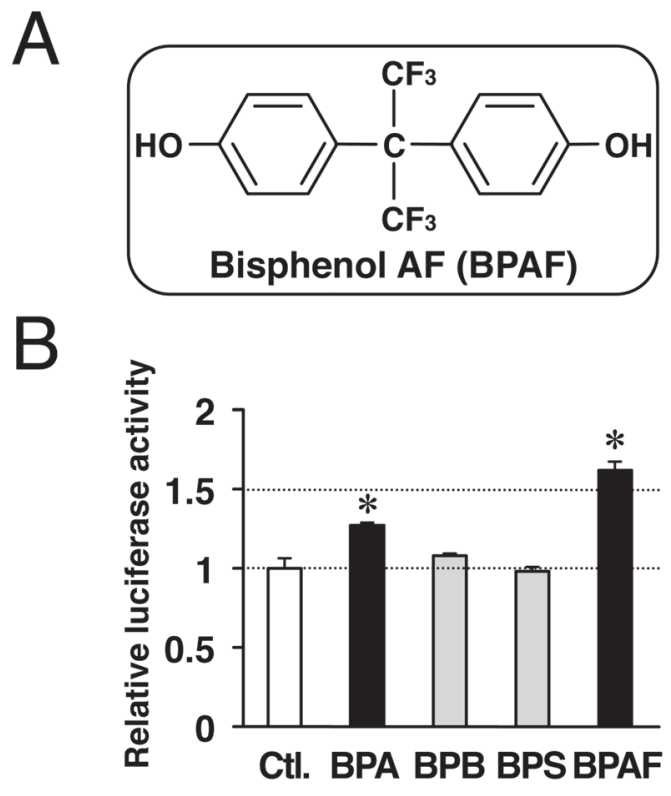

Fig. 1. BPAF-mediated stimulation of transcriptional activity mediated by ERs in MDA-MB-231 cells. (A) Chemical structure of BPAF. (B) MDA-MB-231 cells were transiently transfected with an ERE-luciferase reporter plasmid. After transfection, cells were exposed to four bisphenols: BPA, BPB, BPS, and BPAF, at $25 \mu \mathrm{M}$. After $24 \mathrm{hr}$, cells were harvested and assayed for luciferase activity, and all transfections were normalized for efficiency using the internal Renilla control plasmid. Data are expressed as a fold induction from the vehicle-treated control (Ctl.) (indicated as 1 ), as the mean \pm S.E. $(n=3)$. $*$ Significantly different $(P<0.05)$ from the vehicle-treated control.

for experiments on mRNA expression as well as the transfection analysis (See the dual-luciferase reporter assay).

\section{Transfection and dual-luciferase reporter assay}

Experiments were performed as described previously (Takeda et al., 2013; Okazaki et al., 2017). In brief, $24 \mathrm{hr}$ prior to transfection, MDA-MB-231 and SK-BR-3 cells were seeded $\left(5 \times 10^{4}\right.$ cells/well $)$ on 24 -well plates containing MEM $\alpha$. The transfection of each expression plasmid was performed using Lipofectamine ${ }^{\circledR}$ LTX with PLUS $^{\text {TM }}$ reagent (Invitrogen) according to the manufacturer's instructions. DNA mixtures containing $300 \mathrm{ng}$ of the (estrogen-responsive element, ERE) ${ }_{3}$-Luc plasmid were co-transfected with $2 \mathrm{ng}$ of the Renilla luciferase reporter plasmid ( $\mathrm{pRL}-\mathrm{CMV}$ ) in plates together with an expression plasmid carrying human $\mathrm{ER} \alpha, \mathrm{ER} \beta 1$, or ER $\beta 2$ cDNA (100 ng). Cells were washed with phosphate-buffered saline $24 \mathrm{hr}$ post-transfection and changed to phe- 
nol red-free MEM $\alpha$ supplemented with 5\% dextran-coated charcoal-treated serum, followed by the respective chemical treatments being tested. Cell extracts were then prepared using $100 \mu \mathrm{L}$ of passive lysis buffer (Promega, Madison, WI, USA), and $20 \mu \mathrm{L}$ was then applied to the firefly luciferase and Renilla luciferase assays (Dual-Luciferase Reporter Assay System, Promega). The ratio of firefly luciferase activity (expressed from reporter plasmids) to Renilla luciferase activity (expressed from pRL-CMV) in each sample served as a measure of normalized luciferase activity.

\section{Real-time reverse transcription-polymerase chain reaction (real-time $R T-P C R$ ) analysis}

Total RNA was prepared from MDA-MB-231 cells using the RNeasy kit (Qiagen, Inc., Hilden, Germany) and purified using RNeasy/QIAamp columns (Qiagen, Inc.). In the real-time RT-PCR analysis of ER $\beta 1, E R \beta 2$, and $\beta$-actin, cDNA was prepared via RT of total RNA using the ReverTra Ace ${ }^{\circledR}$ qPCR RT kit (Toyobo Co., Ltd., Osaka, Japan). Real-time quantitative RT-PCR assays were performed with FastStart Essential DNA Green Master (Roche Applied Science, Indianapolis, IN, USA). The primers used for PCR on human ER $\beta 1, E R \beta 2$, and $\beta$-actin were from previous studies (Leung et al., 2006; Takeda et al., 2013). Target mRNA levels were normalized to the corresponding $\beta$-actin mRNA levels. Quantification cycle $(\mathrm{Cq})$ values were assessed in order to compare expression between ER $\beta 1$ and ER $\beta 2$ (Fig. 2A).

\section{Data analysis}

Differences were considered to be significant when the $P$ value was calculated as less than 0.05 . Significant differences between two groups were calculated by the Student's $t$-test. A data analysis of differences among multiple groups was performed using Dunnett's test. Calculations were performed using Statview 5.0J software (SAS Institute Inc., Cary, NC, USA).

\section{RESULTS AND DISCUSSION}

\section{Effects of BPAF on ER-mediated transcriptional activities}

We recently reported that BPAF (Fig. 1A) "up-regulates" the expression of ER $\beta$ at markedly higher concentrations (i.e., $25 \mu \mathrm{M}$ ), and this is associated with the suppression of estrogen signaling in MCF-7 cells (Okazaki et al., 2017). MCF-7 cells express both isoforms of ERs, and intermolecular interactions between ER $\alpha$ and ER $\beta$, which may result in changes in estrogen signaling, have been reported (Powell and $\mathrm{Xu}, 2008$; Shanle and
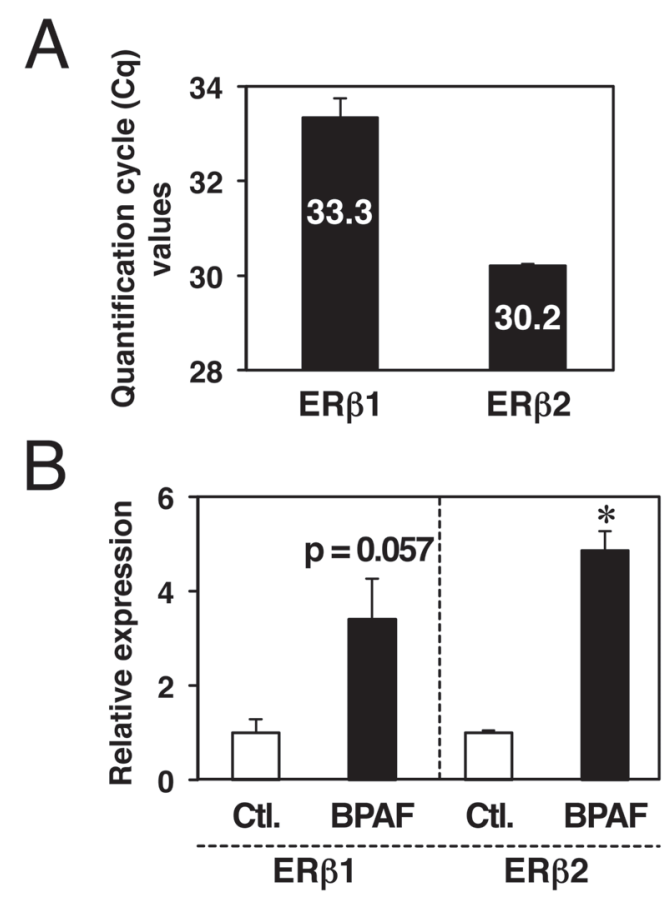

Fig. 2. BPAF-mediated up-regulation of ER $\beta 1$ and ER $\beta 2$ expression in MDA-MB-231 cells. (A) Real-time RTPCR analyses of ER $\beta 1$ and ER $\beta 2$ in MDA-MB-231 cells (basal expression levels). Quantification cycle (Cq) values for ER $\beta 1$ and ER $\beta 2$ are indicated. Data are expressed as the mean \pm S.E. $(n=3)$. (B) Real-time RT-PCR analyses of ER $\beta 1$ and ER $\beta 2$ in MDA-MB231 cells $48 \mathrm{hr}$ after the treatment with vehicle (control) and BPAF $(25 \mu \mathrm{M})$. Data are expressed as a fold induction from the vehicle-treated control (Ctl.) (indicated as 1$)$, as the mean \pm S.E. $(n=3)$. *Significantly different $(P<0.05)$ from the vehicle-treated control.

Xu, 2011; Takeda et al., 2013; Takeda, 2014). In order to clarify/investigate the actions of BPAF on the ER $\beta$ isoform, we herein focused on another human breast cancer cell line, MDA-MB-231, which only expresses ER $\beta$ transcripts (an ER $\alpha$-negative cell line) (Weigel and deConinck, 1993; Takeda et al., 2013). A previous study reported that ER $\beta$ dispatches signals to its downstream pathways, even in the absence of its ligands, which is different from unliganded ERa (Vivar et al., 2010). If this is the case for the result described above, and if BPAF also stimulates the expression of ER $\beta$ in MDA-MB-231 cells, EREmediated transcription may be activated. As shown in Fig. 1B, BPAF at $25 \mu \mathrm{M}$ exhibited the strongest activation effects on ERE-mediated transcription among the other representative bisphenols tested ( $>1.5$-fold), followed by BPA, a parent compound of BPAF $(\sim 1.25$-fold), indicating that the highest transcription activity by BPAF 
is mediated by $\mathrm{ER} \beta$.

There are five splicing variants of ER $\beta$ : ER $\beta 1$ (wildtype), ER $\beta 2$ (also called ER $\beta c x$ ), ER $\beta 3$ (a form restricted to the testis), ER $\beta 4$, and ER $\beta 5$ (Moore et al., 1998; Leung et al., 2006; Sugiyama et al., 2010). Although the physiological activities of the ER $\beta 2 / E R \beta 4 / E R \beta 5$ isofor$\mathrm{ms}$ in breast cancer cells currently remain unclear, ER $\beta 1$ has been shown to exhibit transcriptional activity through ERE, and ER $\beta 2$ itself cannot stimulate ERE-driven activity, even in the presence of E2 (Leung et al., 2006). We initially studied the basal expression profiles of ER $\beta \mathrm{s}$ in MDA-MB-231 cells. A real-time RT-PCR analysis revealed that the expression of ER $\beta 2$ was approximately 8 -fold stronger than that of ER $\beta 1$ (Fig. 2A). The expression signals of ER $\beta 4$ and $\beta 5$ were not detected (data not shown). The expression profiles of the ER $\beta$ isoforms obtained in this study were consistent with those reported by Leung et al. (2006). ER $\beta 1$ and ER $\beta 2$ expression levels were then investigated after exposure to BPAF $(25 \mu \mathrm{M})$. As shown in Fig. 2B, the expression of two ER $\beta$ isoforms
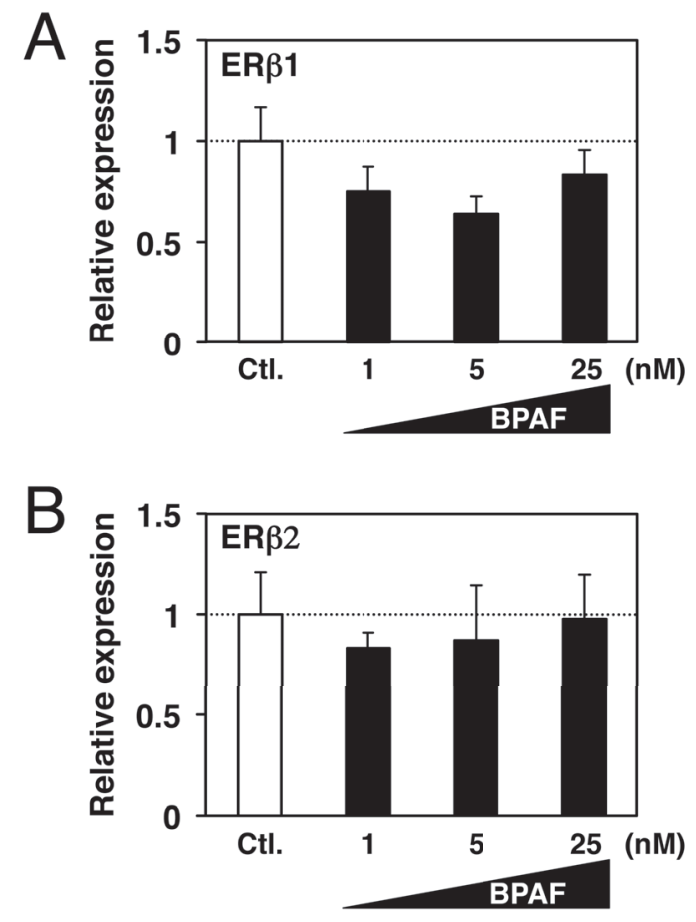

Fig. 3. Effects of BPAF on ER $\beta 1$ and ER $\beta 2$ expression in MDA-MB-231 cells. Real-time RT-PCR analyses of (A) ER $\beta 1$ and (B) ER $\beta 2$ in MDA-MB-231 cells $48 \mathrm{hr}$ after the treatment with vehicle (Control: Ctl.) and $\operatorname{BPAF}(1,5$, and $25 \mathrm{nM})$. Data are expressed as a fold induction from the Ctl. (indicated as 1), as the mean \pm S.E. $(n=6)$. was up-regulated, and the positive modulation of ER $\beta 2$ was significant (4.9-fold, $P<0.05$ ). In contrast to ER $\beta 1$ and ER $\beta 2$ isoforms, the expression signals of ER $\beta 4$ and ER $\beta 5$ were not obtained due to below detection limits (data not shown), and the expression of ER $\alpha$ was not significantly modulated by $25 \mu \mathrm{M}$ BPAF (relative expression; $1.53 \pm 0.42, \mathrm{p}=0.39$ ) when compared to vehicle-treated control. Moreover, the expression of ER $\beta 1$ and ER $\beta 2$ was not affected by BPAF at concentrations ranging between 1 and $25 \mathrm{nM}$ (Fig. 3). Although the ER $\beta 2$ isoform was shown to have undetectable affinity for E2 (Leung et al., 2006), no experimental evidence to show that BPAF modifies the function of ER $\beta 2$ was obtained. We utilized MDAMB-231 cells transfected with an expression plasmid carrying human ER $\beta 2$ cDNA. Similar to E2, no modulative effects by BPAF on ER $\beta 2 / E R E$ up to $25 \mu \mathrm{M}$ were observed (Fig. 4), suggesting that BPAF activates ERE-driven transcription possibly via ER $\beta 1$ (See Fig. 1B) in MDA-MB231 cells. In subsequent experiments, we focused on the interplay between BPAF and the ER $\beta 1$ isoform from the standpoint of transcriptional activation of the receptor after its interaction with ER $\beta 1$.

\section{Effects of BPAF on ER $\beta 1$-mediated transcriptional activities}

Although BPAF has been recognized as a stimulator of ER $\alpha$ in many cancer cell lines that were established

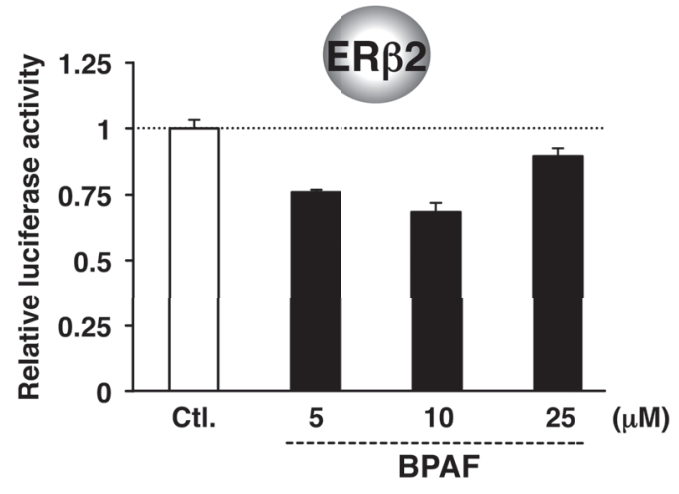

Fig. 4. Effects of BPAF on ER $\beta 2$-mediated transcriptional activity in MDA-MB-231 cells. MDA-MB-231 cells were transiently transfected with an ERE-luciferase reporter plasmid in combination with ER $\beta 2 \mathrm{cDNA}$. After transfection, cells were treated with $\operatorname{BPAF}(5,10$, and $25 \mu \mathrm{M}$ ). After $24 \mathrm{hr}$, cells were harvested and assayed for luciferase activity, and all transfections were normalized for efficiency using the internal Renilla control plasmid. Data are expressed as a fold induction from the vehicle-treated control (Ctl.) (indicated as $1)$, as the mean \pm S.E. $(n=3)$. *Significantly different $(P<0.05)$ from the vehicle-treated control. 

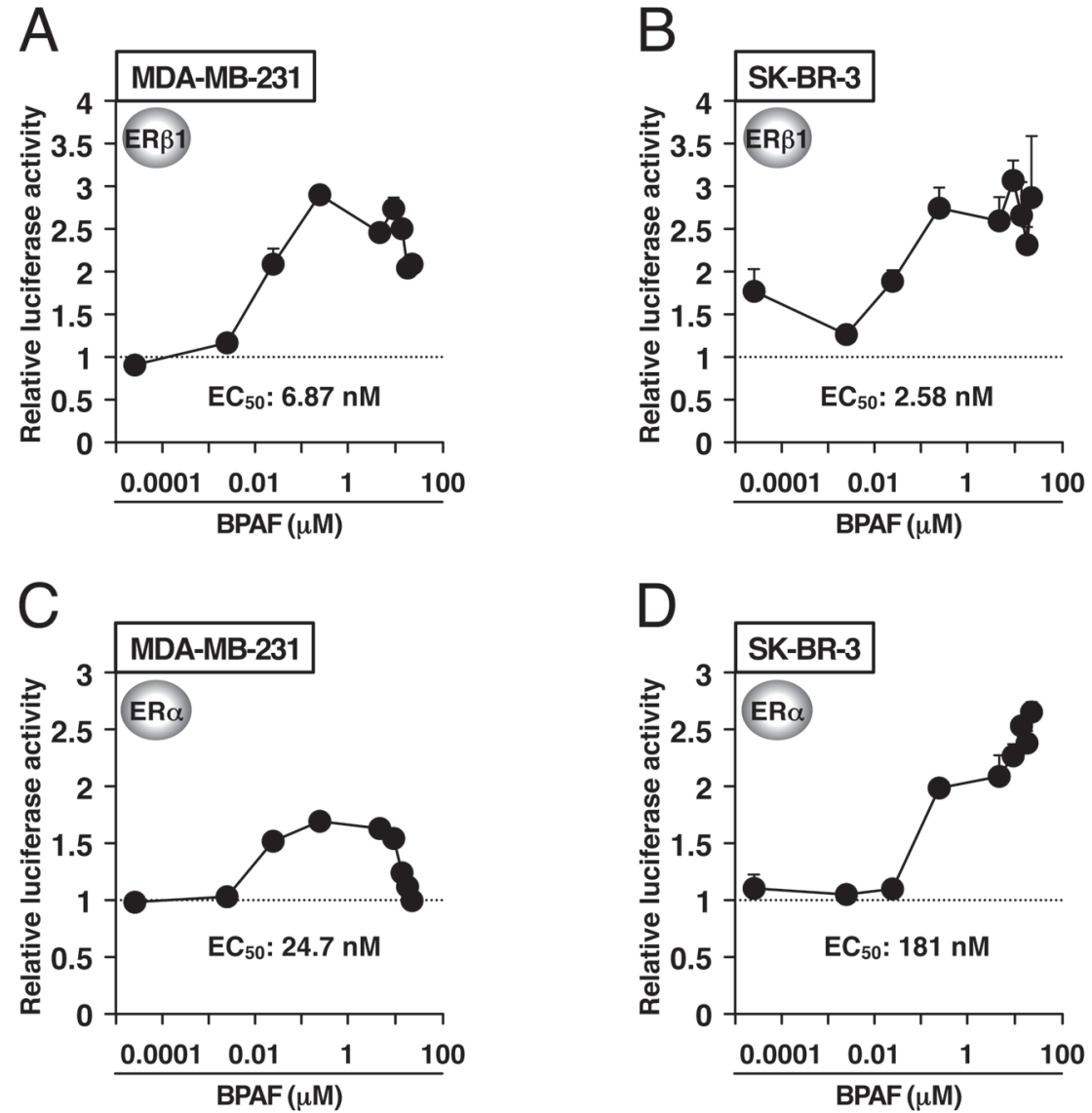

Fig. 5. Effects of BPAF on ER $\beta 1$ - and ER $\alpha$-mediated transcriptional activity in breast cancer cells. (A and C) MDA-MB-231 cells and (B and D) SK-BR-3 cells and were transiently transfected with an ERE- luciferase reporter plasmid in combination with ER $\beta 1$ or ER $\alpha$ cDNAs. After transfection, cells were treated with BPAF ranging between $25 \mathrm{pM}$ and $25 \mu \mathrm{M}$. After $24 \mathrm{hr}$, cells were harvested and assayed for luciferase activity, and all transfections were normalized for efficiency using the internal Renilla control plasmid; the expression of ER $\beta 1$ and ER $\alpha$ was increased approximately 6000 -fold and 90000 -fold by cDNA introduction, respectively, in these breast cancer cells. Data are expressed as a fold induction from the vehicletreated control (Ctl.) (indicated as 1$)$, as the mean \pm S.E. $(n=3)$. *Significantly different $(P<0.05)$ from the vehicle- treated control.

from different organs (Matsushima et al., 2010; Li et al., 2012), a focus on the other isoform, ER $\beta$, proposed a largely unaddressed question as to whether BPAF is also a "stimulator" of ER $\beta$ because BPAF not only exhibits agonistic potential against ER $\beta$, but also lacks modulation potential, which, for example, was observed in human cervical cancer HeLa cells (Matsushima et al., 2010; Li et al., 2012). In the present study, we utilized two types of human breast cancer cell lines, SK-BR-3 and MDA-MB-231 cells, the former of which is entirely negative for both ERs and the latter is known as ER $\alpha$ $(-) / E R \beta$ (very low) (Okazaki et al., 2017). As shown in Figs. 4A and B, in the MDA-MB-231 and SK-BR-3 cell lines transfected with human ER $\beta 1$ cDNA, BPAF activat- ed ER $\beta 1$-mediated transcriptional activity in a concentration-dependent manner, giving $\mathrm{EC}_{50}$ values of 6.87 and $2.58 \mathrm{nM}$, respectively. ER $\alpha$ activity was positively stimulated by BPAF in both cell lines ( $\mathrm{EC}_{50}$ values: 24.7 and $181 \mathrm{nM}$ ), although $\mathrm{ER} \alpha$ activity at higher concentrations (higher than $15 \mu \mathrm{M}$ ) slightly decreased in MDA-MB-231 cells (Figs. 5C and 5D). It is important to note that the activation of ER $\beta 1$ by BPAF was observed at markedly lower concentrations that those for ER $\alpha$, and this concentration is relevant to environmental levels (Yang et al., 2014). 


\section{H. Okazaki et al.}

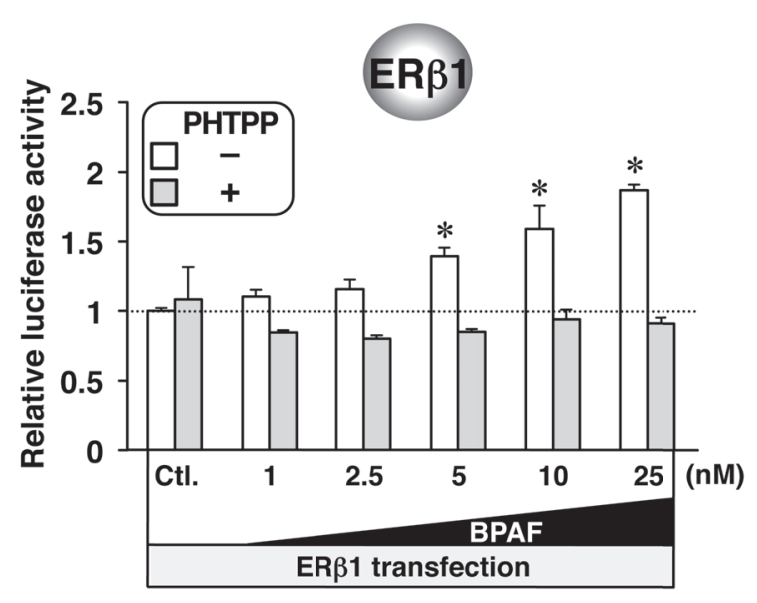

Fig. 6. Effects of BPAF on ER $\beta 1$-mediated transcriptional activity in MDA-MB-231 cells. MDA-MB-231 cells were transiently transfected with an ERE-luciferase reporter plasmid in combination with ER $\beta 1 \mathrm{cDNA}$. After transfection, cells were treated with BPAF at concentrations ranging between $1 \mathrm{nM}$ and $25 \mathrm{nM}$ in the presence $(+)$ or absence $(-)$ of $1 \mu \mathrm{M}$ PHTPP. In the system without PHTPP, an equivalent volume of vehicle was added. After $24 \mathrm{hr}$, cells were harvested and assayed for luciferase activity, and all transfections were normalized for efficiency using the internal Renilla control plasmid. Data are expressed as a fold induction from the vehicle-treated control (Ctl.) (indicated as $1)$, as the mean \pm S.E. $(n=3)$. *Significantly different $(P<0.05)$ from the vehicle-treated control.

\section{Effects of an ER $\beta$ antagonist on BPAF-mediated transcription of ER $\beta 1$}

In order to investigate whether BPAF directly activates the transcriptional activity of ER $\beta 1$, PHTPP, a highly selective ER $\beta$ antagonist, was introduced into the reaction system of ER $\beta 1 / E R E$ along with BPAF in MDAMB-231 cells. As shown in Fig. 6, the concentration-dependent stimulation of ER $\beta 1$ activity was reproducibly demonstrated up to $25 \mathrm{nM}$ (See also Fig. 5A), and BPAFstimulated activity was effectively abrogated by the presence of $1 \mu \mathrm{M}$ PHTPP, a selective full antagonist of the ER $\beta$ isoform (Compton et al., 2004), to control levels. It is important to note that when we focused on the control system (Ct1.), no observable modulation was detected by PHTPP alone, suggesting that PHTPP inhibited ER $\beta 1$ transcriptional activity stimulated by BPAF only. As described above, since the expression of ER $\beta 1$ was not up-regulated by BPAF in the concentration range of $25 \mathrm{nM}$ or less (Fig. 3A), BPAF appears to function as an activator of ER $\beta 1$-mediated transcription in the nanomolar concentration range. We recently reported that BPAF has the potential to up-regulate $\mathrm{ER} \beta$ at the $\mathrm{mRNA} /$ protein level in human breast cancer cells at relatively "higher concentrations" $(25 \mu \mathrm{M})$ (Okazaki et al., 2017). In addition, BPAF has been shown to exhibit abnormal behavior; although its $\log P_{\text {ow }}$ (i.e., $n$-octanol/water: 2.82 ) is smaller than that of BPA (3.32), its clearance from hepatocytes is markedly slower than BPA, indicating that BPAF accumulates in cells, possibly leading to unwanted toxicological outcomes (HSDB, 2001; NTP, 2008; Waidyanatha et al., 2015). These findings suggest that BPAF acts as an endocrine disruptor underlying the dual activation of ER $\beta 1$, i) a direct activator for the ER $\beta 1$ ligand at low concentrations (nM order) and ii) the induction of ER $\beta$ at high concentrations ( $\mu \mathrm{M}$ order). Since bisphenols are detected in human biological samples (Yang et al., 2014), BPAF is able to evoke its unwanted effects on breast tissues through interactions with ER $\beta$ rather than ER $\alpha$. Although we mainly focused on the interaction between BPAF and ER $\beta 1$ (genomic effects), one of the alternatively spliced transcript variants of the ESR2 gene, to comprehensively understand the biological (toxicological) profiles of BPAF, further studies that consider the involvement of the $G$ protein-coupled estrogen receptor pathway, which has recently been reported to be involved in BPAF-mediated non-genomic estrogenic effects in breast cancer SK-BR-3 cells (Cao et al., 2017), are needed.

\section{ACKNOWLEDGMENTS}

This research was supported by EXTEND2010 grants from the Ministry of the Environment, Japan (to H.A.). This study was also supported in part by Grants-in-Aid for Scientific Research (C) [25460182 and 17K08402, (to S.T.)] from the Japan Society for the Promotion of Science (JSPS) KAKENHI.

Conflict of interest---- The authors declare that there is no conflict of interest.

\section{REFERENCES}

Cao, L.Y., Ren, X.M., Li, C.H., Zhang, J., Qin, W.P., Yang, Y., Wan, B. and Guo, L.H. (2017): Bisphenol AF and bisphenol B exert higher estrogenic effects than bisphenol A via G protein-coupled estrogen receptor pathway. Environ. Sci. Technol., 51, 1142311430.

Compton, D.R., Sheng, S., Carlson, K.E., Rebacz, N.A., Lee, I.Y., Katzenellenbogen, B.S. and Katzenellenbogen, J.A. (2004): Pyrazolo[1,5- $a]$ pyrimidines: estrogen receptor ligands possessing estrogen receptor $\beta$ antagonist activity. J. Med. Chem., 47, 5872-5893. [Erratum in J. Med. Chem., 48, 2724 (2005)]

HSDB. (2001): BISPHENOL A. Bethesda, MD, National Library of Medicine, Hazardous Substances Data Bank. Available at http:// 
BPAF activation of ER $\beta 1$

toxnet.nlm.nih.gov/cgi-bin/sis/htmlgen?HSDB.

Leung, Y.K., Mak, P., Hassan, S. and Ho, S.M. (2006): Estrogen receptor (ER) $-\beta$ isoforms: a key to understanding ER- $\beta$ signaling. Proc. Natl. Acad. Sci. USA, 103, 13162-13167. [Erratum in Proc. Natl. Acad. Sci. USA., 103, 14977 (2006)]

Li, Y., Burns, K.A., Arao, Y., Luh, C.J. and Korach, K.S. (2012): Differential estrogenic actions of endocrine-disrupting chemicals bisphenol A, bisphenol AF, and zearalenone through estrogen receptor $\alpha$ and $\beta$ in vitro. Environ. Health Perspect., 120, 10291035. [Erratum in Environ. Health Perspect., 120, A455 (2012)]

Matsushima, A., Liu, X., Okada, H., Shimohigashi, M. and Shimohigashi, Y. (2010): Bisphenol AF is a full agonist for the estrogen receptor ERalpha but a highly specific antagonist for ERbeta. Environ. Health Perspect., 118, 1267-1272.

Moore, J.T., McKee, D.D., Slentz-Kesler, K., Moore, L.B., Jones, S.A., Horne, E.L., Su, J.L., Kliewer, S.A., Lehmann, J.M. and Willson, T.M. (1998): Cloning and characterization of human estrogen receptor $\beta$ isoforms. Biochem. Biophys. Res. Commun., 247, 75-78.

National Toxicology Program (NTP). (2008): Chemical Information Profile for Bisphenol AF [CAS No. 1478-61-1]. NTP, National Institute of Environmental Health Sciences, National Institutes of Health, U.S. Department of Health and Human Services. Supporting Nomination for Toxicological Evaluation by NTP. Available online: http://ntp.niehs.nih.gov/ntp/htdocs/Chem_Background/ExSumPdf/BisphenolAF 093008 508.pdf.

Okazaki, H., Takeda, S., Kakizoe, K., Taniguchi, A., Tokuyasu, M., Himeno, T., Ishii, H., Kohro-Ikeda, E., Haraguchi, K., Watanabe, K. and Aramaki, H. (2017): Bisphenol AF as an inducer of estrogen receptor $\beta$ (ER $\beta)$ : evidence for anti-estrogenic effects at higher concentrations in human breast cancer cells. Biol. Pharm. Bull., 40, 1909-1916.

Powell, E. and Xu, W. (2008): Intermolecular interactions identify ligand-selective activity of estrogen receptor $\alpha / \beta$ dimers. Proc. Natl. Acad. Sci. USA, 105, 19012-19017.

Rochester, J.R. (2013): Bisphenol A and human health: a review of the literature. Reprod. Toxicol., 42, 132-155.
Shanle, E.K. and Xu, W. (2011): Endocrine disrupting chemicals targeting estrogen receptor signaling: identification and mechanisms of action. Chem. Res. Toxicol., 24, 6-19.

Sugiyama, N., Barros, R.P., Warner, M. and Gustafsson, J.A. (2010): ER $\beta$ : recent understanding of estrogen signaling. Trends Endocrinol. Metab., 21, 545-552.

Takeda, S., Okajima, S., Miyoshi, H., Yoshida, K., Okamoto, Y., Okada, T., Amamoto, T., Watanabe, K., Omiecinski, C.J. and Aramaki, H. (2012): Cannabidiolic acid, a major cannabinoid in fiber-type cannabis, is an inhibitor of MDA-MB-231 breast cancer cell migration. Toxicol. Lett., 214, 314-319.

Takeda, S., Yoshida, K., Nishimura, H., Harada, M., Okajima, S., Miyoshi, H., Okamoto, Y., Amamoto, T., Watanabe, K., Omiecinski, C.J. and Aramaki, H. (2013): $\Delta\left({ }^{9}\right)$ Tetrahydrocannabinol disrupts estrogen-signaling through upregulation of estrogen receptor $\beta$ (ER $\beta)$. Chem. Res. Toxicol., 26, 1073-1079.

Takeda, S. (2014): $\Delta^{9}$-Tetrahydrocannabinol targeting estrogen receptor signaling: the possible mechanism of action coupled with endocrine disruption. Biol. Pharm. Bull., 37, 1435-1438.

Vivar, O.I., Zhao, X., Saunier, E.F., Griffin, C., Mayba, O.S., Tagliaferri, M., Cohen, I., Speed, T.P. and Leitman, D.C. (2010): Estrogen receptor $\beta$ binds to and regulates three distinct classes of target genes. J. Biol. Chem., 285, 22059-22066.

Waidyanatha, S., Mathews, J.M., Patel, P.R., Black, S.R., Snyder, R.W. and Fennell, T.R. (2015): Disposition of bisphenol AF, a bisphenol A analogue, in hepatocytes in vitro and in male and female Harlan Sprague-Dawley rats and B6C3F1/N mice following oral and intravenous administration. Xenobiotica, 45, 811-819.

Weigel, R.J. and deConinck, E.C. (1993): Transcriptional control of estrogen receptor in estrogen receptor-negative breast carcinoma. Cancer Res., 53, 3472-3474.

Yang, Y., Guan, J., Yin, J., Shao, B. and Li, H. (2014): Urinary levels of bisphenol analogues in residents living near a manufacturing plant in south China. Chemosphere, 112, 481-486. 